\title{
Nitrogen Metabolism in Zucker Rats is Affected by Moderate Reduction, but not by Moderate Increase in Dietary Protein
}

\author{
Immaculada Rafecas ${ }^{1}$ and Xavier Remesar ${ }^{2,3, *}$ \\ ${ }^{1}$ Grup Nitrogen-Obesitat and ${ }^{2}$ Departament de Nutrició i Bromatologia, Facultat de Biologia, Universitat de Barcelona, \\ Spain, ${ }^{3}$ CIBER Fisiopatología de la Obesidad y Nutrición, Instituto de Salud Carlos III, Spain
}

\begin{abstract}
Marked changes in the content of protein in the diet affects the rat's pattern of growth, but there is not any data on the effects to moderate changes. Here we used a genetically obese rat strain (Zucker) to examine the metabolic modifications induced to moderate changes in the content of protein of diets, doubling (high-protein (HP): $30 \%$ ) or halving (low-protein (LP): $8 \%$ ) the content of protein of reference diet (RD: 16\%).

Nitrogen, energy balances, and amino acid levels were determined in lean (L) and obese (O) animals after 30 days on each diet. Lean HP (LHP) animals showed higher energy efficiency and amino acid catabolism but maintained similar amino acid accrual rates to the lean RD (LRD) group. Conversely, the lean LP (LLP) group showed a lower growth rate, which was compensated by a relative increase in fat mass. Furthermore, these animals showed greater efficiency accruing amino acids. Obesity increased amino acid catabolism as a result of massive amino acid intake; however, obese rats maintained protein accretion rates, which, in the OHP group, implied a normalization of energy efficiency. Nonetheless, the obese OLP group showed the same protein accretion pattern as in lean animals (LLP). In the base of our data, concluded that the Zucker rats accommodate their metabolism to support moderates increases in the content of protein in the diet, but do not adjust in the same way to a $50 \%$ decrease in content of protein, as shown by an index of growth reduced, both in lean and obese rats.
\end{abstract}

Keywords: Amino acid accretion, diet, nitrogen balance, protein content, Zucker rats.

\section{INTRODUCTION}

During mammalian development dietary protein is essential to normal growth [1], varying the index of protein accretion during development [2], caused by changes in the quality and quantity of food ingested [3]. Changes in the protein accretion rate [2] and in free amino acid pools in rat tissues during the transition from dietary milk to solid food [4] are well documented. However, there is scarce information about the destination of amino acids during the juvenile period in the rat. Diets with protein imbalances decrease food intake and growth $[5,6]$ and alter protein metabolism and turnover [7]. Therefore the effect of content of dietary protein during the juvenile period can also be critical for the normal development of the rat, and in control of body weight [8]. Besides, the content of protein of the diet also can affect the destination of free amino acid pool in tissues [9]. The obese Zucker rats show hyperfagia and an efficient energy storage capacity [10], and have lower muscular mass and muscular protein content than their lean counterparts [11], which contrasts with the similar total body protein content shown in 60-day-old obese rats [12]. However, some studies report that these obese animals maintain a relative normal protein metabolism [13].

*Address correspondence to this author at the Departament de Nutrició i Bromatologia, Facultat de Biologia, Universitat de Barcelona, Av. Diagonal 643, 08028 Barcelona, Spain; Tel. +34 934021518; Fax +34 934037064;

E-mail: xremesar@ub.edu
Here we examined the effects caused by moderate chronic variations in dietary protein (in the range of generally found in standard human diets) on nitrogen and amino acid balances, to determine the capacity of young animals to adapt to these diets. Furthermore, we tried to verify if the increase of protein content in the diet could act to slow down the development of obesity.

\section{METHODS AND MATERIALS}

\section{Animals and diets}

Male lean $(\mathrm{Fa} /$ ?) or obese (fa/fa) Zucker rats (from Harlan Laboratory Models stock, Sant Feliu de Codines, Spain) were housed under controlled conditions (temperature $21-22^{\circ} \mathrm{C} ; 12 / 12 \mathrm{~h}$ light/dark cycle, and humidity $65-75 \%$ ). A group of 30-day-old animals (Lean and Obese) were killed and used to determine the initial body composition and their energy content. Meanwhile other 30-day-old animals were randomly assigned to one of the following ad libitum diets for 30 days: standard (Reference Diet (RD): 9\% water, 3\% lipid, $16 \%$ protein and $61 \%$ digestible carbohydrate $(20 \%$ of protein-derived energy)), high protein (HP diet: $12 \%$ water, $3 \%$ lipid, $30 \%$ protein, $45 \%$ digestible carbohydrate $(36 \%$ of protein-derived energy)) or low protein (LP diet: 9\% water, $3 \%$ lipid, $8 \%$ protein, and $71 \%$ digestible carbohydrate ( $9.5 \%$ of protein-derived energy)). Thus, the animals on dietary treatment lean (L) or obese (O) were randomly divided into the following groups: reference diet (LRD and ORD), high-protein diet (LHP and OHP) and low-protein diet (LLP and OLP). The diets were purchased from Harlan 
Table 1. Changes in Body Weight, Body Composition and Energy Balance in Zucker Lean and Obese Rats

\begin{tabular}{|c|c|c|c|c|c|c|c|}
\hline \multicolumn{4}{|c|}{ Lean Zucker } & \multicolumn{4}{|c|}{ Obese Zucker } \\
\hline & LRD & LHP & LLP & ORD & ОНР & OLP & Anova \\
\hline \multicolumn{8}{|l|}{ Body weight } \\
\hline Day $30(\mathrm{~g})$ & $53.1 \pm 3.99$ & $58.3 \pm 2.75$ & $55.1 \pm 3.14$ & $83.6 \pm 1.99$ & $85.2 \pm 3.14$ & $88.4 \pm 2.85$ & S \\
\hline Day $60(\mathrm{~g})$ & $187 \pm 9.71$ & $213 \pm 5.41 *$ & $84.5 \pm 3.17 *$ & $301 \pm 9.31$ & $284 \pm 4.41$ & $185 \pm 8.72 *$ & $\mathrm{~S}, \mathrm{D}$ \\
\hline Increase/day & $4.42 \pm 0.19$ & $5.14 \pm 0.19^{*}$ & $0.67 \pm 0.13^{*}$ & $7.48 \pm 0.21$ & $6.76 \pm 0.15^{*}$ & $2.95 \pm 0.24 *$ & $\mathrm{~S}, \mathrm{D}$ \\
\hline \multicolumn{8}{|c|}{ Body final Composition (day 60) } \\
\hline Water $\quad(\%)$ & $67.9 \pm 3.11$ & $65.3 \pm 2.15$ & $65.1 \pm 2.55$ & $53.7 \pm 2.16$ & $52.6 \pm 2.58$ & $51.9 \pm 2.17$ & $\mathrm{~S}$ \\
\hline Lipid $\quad(\%)$ & $6.84 \pm 0.21$ & $7.13 \pm 0.22$ & $11.9 \pm 0.31^{*}$ & $29.4 \pm 1.11$ & $26.1 \pm 1.75$ & $28.1 \pm 1.33$ & $\mathrm{~S}, \mathrm{D}$ \\
\hline Protein $\quad(\%)$ & $20.1 \pm 0.18$ & $21.7 \pm 0.33^{*}$ & $17.8 \pm 0.12 *$ & $14.2 \pm 0.13$ & $14.4 \pm 0.25$ & $15.4 \pm 0.55^{*}$ & $\mathrm{~S}, \mathrm{D}$ \\
\hline Lipid （g) & $12.8 \pm 1.47$ & $15.2 \pm 0.92 *$ & $10.7 \pm 1.01$ & $88.8 \pm 4.07$ & $74.2 \pm 1.66^{*}$ & $51.8 \pm 2.67^{*}$ & $\mathrm{~S}, \mathrm{D}$ \\
\hline Protein $(g)$ & $37.6 \pm 2.74$ & $46.3 \pm 1.05^{*}$ & $15.1 \pm 0.69^{*}$ & $42.9 \pm 2.41$ & $40.9 \pm 0.64$ & $28.6 \pm 3.62^{*}$ & $\mathrm{~S}, \mathrm{D}$ \\
\hline Protein/Lipid ratio & $3.02 \pm 0.24$ & $3.04 \pm 0.19$ & $1.55 \pm 0.21^{*}$ & $0.48 \pm 0.03$ & $0.55 \pm 0.01$ & $0.55 \pm 0.07$ & S, D \\
\hline \multicolumn{8}{|l|}{ Energy content (MJ) } \\
\hline Body (day 60) & $1.39 \pm 0.11$ & $1.71 \pm 0.04$ & $0.78 \pm 0.05^{*}$ & $4.53 \pm 0.19$ & $3.91 \pm 0.07^{*}$ & $2.72 \pm 0.07^{*}$ & S, D \\
\hline Ingested & $6.92 \pm 0.15$ & $6.86 \pm 0.12$ & $3.52 \pm 0.23 *$ & $10.4 \pm 0.41$ & $10.1 \pm 0.22$ & $6.84 \pm 0.43^{*}$ & $\mathrm{~S}, \mathrm{D}$ \\
\hline Accrued* & $1.07 \pm 0.09$ & $1.33 \pm 0.05$ & $0.43 \pm 0.04 *$ & $3.69 \pm 0.18$ & $3.04 \pm 0.06^{*}$ & $1.81 \pm 0.12^{*}$ & S, D \\
\hline Efficiency (\%) & $15.4 \pm 1.30$ & $19.4 \pm 0.77^{*}$ & $12.1 \pm 0.91^{*}$ & $35.4 \pm 0.77$ & $29.5 \pm 0.61^{*}$ & $26.4 \pm 0.53^{*}$ & S, D \\
\hline
\end{tabular}

Two-way ANOVA (Diet (D), Strain (S)) $\mathrm{P}<0.05$. Bonferroni post-hoc test: $*=\mathrm{P}<0.05$ vs RD diet.

*: The average values of the lean and obese animals killed on day 30 were used to estimate the energy accrued: Lean $=0.33 \pm 0.02(\mathrm{MJ})$ and Obese $=0.82 \pm 0.10(\mathrm{MJ})$

Laboratory Models, Sant Feliu de Codines, Spain) and were isocaloric, with a mean net energy content of $13.6 \mathrm{~kJ} / \mathrm{g}$.

Animal protocols followed European Union guidelines and were approved by the Ethical Committee of the University of Barcelona.

\section{Procedure}

The animals under dietary treatment were placed in metabolic cages and the daily variations in body weight, and food and water intake were measured. Daily depositions, in the form of urine (conserved with $1 \mathrm{mM} \mathrm{HCl}$ to minimize $\mathrm{N}$ losses) and droppings were collected, weighed, frozen and stored at $-20^{\circ} \mathrm{C}$. 30-days-old rats were used to calculate balances.

Animals were anesthetized with ethyl ether and $2 \mathrm{ml}$ of blood was removed through heart puncture and used to obtain plasma. The rats were then killed by excess of anesthesia, dissected, cleaned of intestinal contents, weighed again and sealed in polyethylene bags, which were subsequently autoclaved at $120^{\circ} \mathrm{C}$ for $2 \mathrm{~h}$. Each whole rat was then minced to a smooth paste with a blender. The paste of both 30 and 60-day-old animals was used to estimate the water, lipid [14], energy (bomb calorimeter, C-7000, IKA, Heitersheim, Germany) and nitrogen content. The latter was measured as total $\mathrm{N}$ by means of an elemental analyzer (Carlo Erba NA-1500, Milano, Italy), and then converted into protein content using a factor of 5.5 [12].

The samples of droppings were frozen in liquid nitrogen, minced and homogenized. An aliquot of each sample was mixed with all the other samples, proportionally to the respective daily weight, thereby obtaining a single sample representative of the whole period studied. This sample was used to determine total $\mathrm{N}$ content in faeces. The same procedure was used with samples of urine and, the final sample was used both for total $\mathrm{N}$ determination and for analysis of amino acid content. The $\mathrm{N}$ content of the diet was also determined, which, together with its content in faeces and urine and total homogenate, was used to estimate nitrogen balance [15].

Samples of paste were homogenized with a cellular disruptor, and proteins were then hydrolyzed with $6 \mathrm{~N} \mathrm{HCl}$ in sealed glass tubes under nitrogen at $105^{\circ} \mathrm{C}$ for $48 \mathrm{~h}$, as previously described [16]. Next, the hydrolysates were cleared by ultrafiltration and neutralized. Free amino acids in plasma and urine and also amino acids in protein hydrolysates were determined with an ALPHA-PLUS (Pharmacia, Uppsala, Sweden) amino acid analyzer. Gln + Glu values were referred as Glx, and Asp + Asn values were referred as Asx.

Balances were calculated from data on the mean body composition on day 30 and the individual final body analysis (day 60).

Animals were randomly distributed into groups, each with 5-7 specimens. Statistical comparison between groups was carried out using a two-way ANOVA with the program Prism 4 (GraphPad Software Inc, San Diego, CA, USA). A post-hoc Bonferroni test was used for individual comparisons.

\section{RESULTS}

The changes in content of dietary protein affected the pattern of growth in both lean and obese animals (Table 1). 
Table 2. Food and Water Intake and Nitrogen Balance in Zucker Lean and Obese Rats

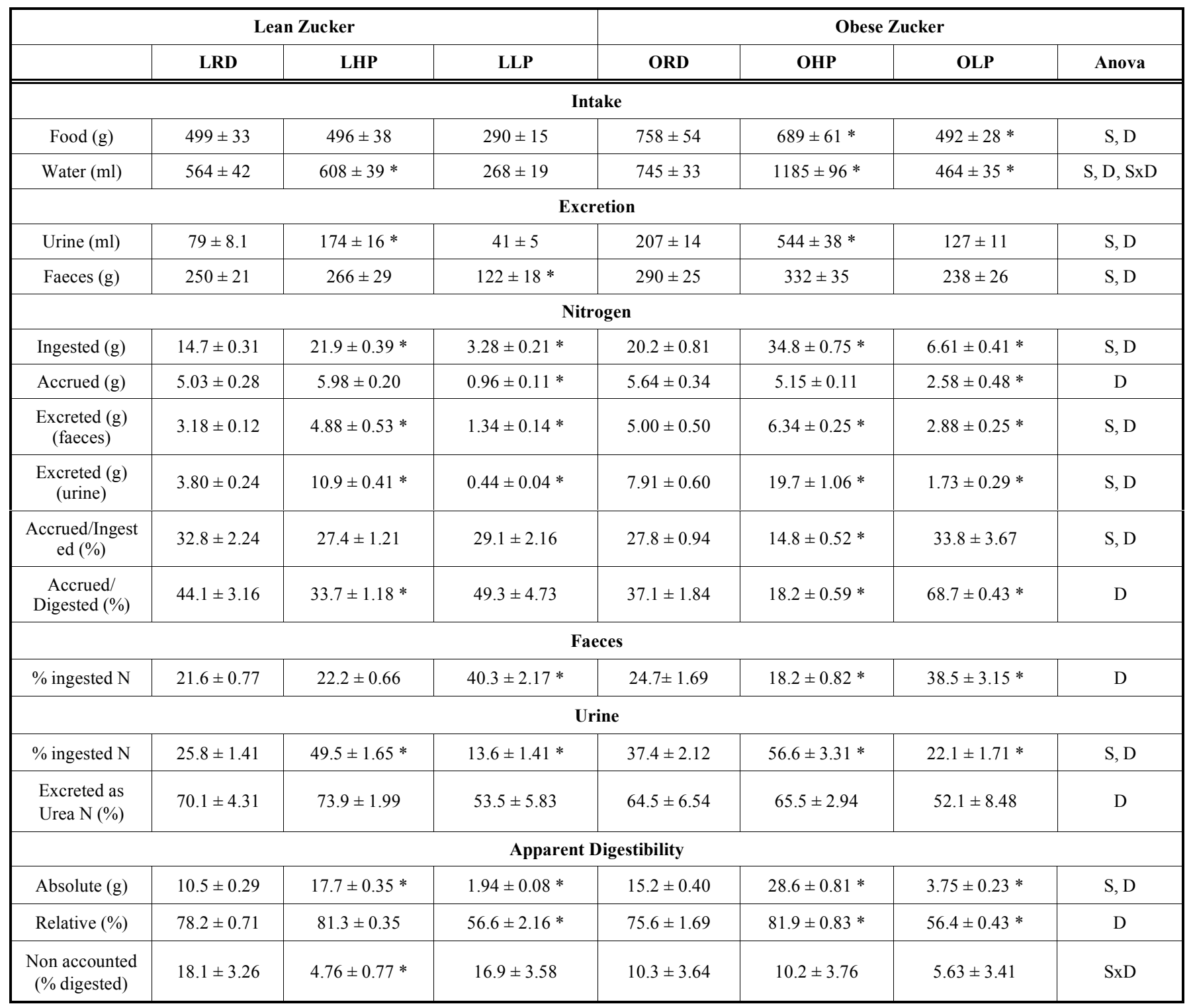

Two-way ANOVA (Diet (D), Strain (S)) $\mathrm{P}<0.05$. Bonferroni post-hoc test: * $=\mathrm{P}<0.05$ vs RD diet.

Thus, LHP rats showed a higher weight than LRD animals, which was caused by an increase both in their lean and fat mass, which lead to an identical Protein/Lipid ratio. This pattern was not reproduced in obese animals, as the final weight of OHP animals did not show any difference, but accumulated fewer lipids than their reference counterparts ORD, and showing a homogeneous Lipid/Protein ratio among obese animals. Animals fed low-protein diets (LLP and OLP) showed lower growth rates. Thus, LLP rats showed an increase in the percentage of lipid content that provokes a decline in the Protein/Lipid ratio. The energy efficiency ratio (accrued energy/ingested energy) increased in LHP animals, whereas this rate decreased in LLP. Obese animals increased the energy intake and the efficiency ratio in spite of their lower values. Animals fed low-protein diets (LLP, OLP) showed lower energy intake than reference-diet and high-protein groups.

Standard plasmatic parameters (data not shown) in these animals coincided with previously described values [17].
Table 2 describes the food and water intake and excretion, together $\mathrm{N}$ balances for the period of 30 days. As expected, high-protein fed rats ingested higher amounts of water and produced more urine than other groups. Roughly, LLP group ingested one fourth of the $\mathrm{N}$ corresponding to $\mathrm{LRD}$ values, divided equally between the decrease in the nitrogen contained in the diet and the decrease in food consumption. A similar trend can be observed in OLP groups. The low levels of $\mathrm{N}$ ingested by LLP and OLP animals were accompanied with a decrease in $\mathrm{N}$ excretion, especially in urine. Furthermore, the efficiency of $\mathrm{N}$ accretion (\% Accrued/Ingested) was maintained in LLP and OLP groups. The pattern in HP groups was different as they showed decreased accretion efficiency values that coincided with a parallel increase in urinary excretion. Furthermore, there were increases in the absolute digestibility value for both HP groups. On the other hand, LP groups present low values for this parameter.

The profiles of amino acid content in the different diets showed the expected similar pattern, with higher levels in the 
Table 3. P Values for the Statistical Significance

\begin{tabular}{|c|c|c|c|c|c|c|c|c|}
\hline & \multicolumn{2}{|c|}{ Plasma } & \multicolumn{2}{|c|}{ Homogenate } & \multicolumn{2}{|c|}{ Intake } & \multicolumn{2}{|c|}{ Urine } \\
\hline Glx & 0.0049 & 0.0001 & NS & 0.0001 & 0.0001 & 0.0001 & 0.0001 & 0.0001 \\
\hline Asx & NS & 0.0001 & 0.0034 & 0.0001 & 0.0001 & 0.0001 & 0.0004 & 0.0432 \\
\hline Ala & NS & 0.0075 & NS & 0.0001 & 0.0001 & 0.0001 & 0.0003 & 0.0003 \\
\hline Pro & 0.0033 & 0.0141 & NS & 0.0001 & 0.0001 & 0.0001 & 0.0001 & 0.0004 \\
\hline $\operatorname{Arg}$ & NS & 0.0018 & NS & 0.0001 & 0.0001 & 0.0001 & NS & 0.0001 \\
\hline Tyr & NS & 0.0119 & 0.0022 & 0.0001 & 0.0001 & 0.0001 & 0.0001 & 0.0001 \\
\hline Phe & NS & 0.0370 & NS & 0.0001 & 0.0001 & 0.0001 & 0.0001 & 0.0001 \\
\hline Thr & 0.0121 & 0.0318 & 0.0017 & 0.0001 & 0.0001 & 0.0001 & 0.0001 & 0.0001 \\
\hline Lys & 0.0088 & 0.0138 & 0.0130 & 0.0001 & 0.0001 & 0.0001 & 0.0019 & 0.0001 \\
\hline His & NS & 0.0192 & 0.0033 & 0.0001 & 0.0001 & 0.0001 & NS & 0.0109 \\
\hline Cys & 0.0779 & NS & NS & 0.0001 & 0.0001 & 0.0001 & 0.0002 & 0.0001 \\
\hline Met & NS & 0.0430 & 0.0222 & 0.0001 & 0.0001 & 0.0001 & & \\
\hline Taurine & & & & & & & 0.0001 & 0.0001 \\
\hline
\end{tabular}

P values for the statistical significance of the effects of different protein content in the diet on amino acid plasma levels ( $\mu \mathrm{M})$, amino acid content in 60 -day homogenate ( $\mu$ mols/g), amino acid intake ( $\mu \mathrm{mols})$ and amino acid excretion in urine ( $\mu$ mols) in lean and obese Zucker rats. Two-way ANOVA (Diet and Strain).

HP and lower ones in LP, when compared with RD groups. Changes in plasma amino acid levels caused by diet are significant for Ala, Asx, Arg, Tyr, Phe, His and Met, whereas in the rest of amino acids the significant differences are caused both by diet and strain (Table 3 ), where LHP and LLP groups tended to show significantly higher plasma amino acid values than the LRD group (Supplemental Table 1). This trend was not detected in obese animals, which showed similar levels for all three diets.

Changes in amino acid homogenate composition at 60 days showed significant differences caused by diet in Glx, Ala, Gly, Pro, Arg, Phe and Val, and in the rest of amino acids the differences were caused by strain and diet (Table $\mathbf{3}$, Supplemental Table 2). Individual amino acid levels in total body homogenates of LHP and OHP animals were similar to those of the respective RD groups, whereas OLP and LLP groups showed significantly lower values.

In the case of amino acid intake, all the amino acids showed significant differences by diet and strain (Table 3, Supplemental Table 3), with higher values for both HP groups and lower ones for the LP groups; being the values of obese group higher than those of their lean littermates. The amino acids excreted by urine showed important variations, being Arg, Leu, Ile and His, those that showed significance only due to the diet, whereas all other amino acids showed significant differences by diet and strain (Table $\mathbf{3}$, Supplemental Table 4).

The accretion rate of individual amino acids showed the same rate for RD and HP, either for lean or obese animals, whereas, the LP groups showed a significant decreased rate (Supplemental Table 5), as expressed by the ANOVA results. When accretion rates were expressed as a percentage of ingested amino acids, mean values for lean animals $(22.5$ $\%$ ) almost double those obtained for obese animals (13.5\%) (Data not shown).

\section{DISCUSSION}

Changes in weight and energy intake of the LRD group were compatible with the range described previously [17]. In contrast, the observation that total $\mathrm{N}$ loss in faeces was similar to that detected in urine does not support previous data [18].

The increased availability of dietary protein allowed the LHP group to exceed the lean reference weight, due to an increase of lean mass, which was accompanied by higher rates of energy efficiency and the maintenance of $\mathrm{N}$ relative apparent digestibility. These data contrast with the current concept that high-protein diets for human use show reduced energy efficiency [19]. The discrepancy may be caused by the magnitude of protein content in relation to total energy content. The adaptation of intestine absorption to chronic ingestion of high protein levels [20,21] can modulate the rate of protein absorption in the LHP group. Furthermore, increased dietary protein elicits amino acid utilization by liver $[22,23]$ and the catabolic utilization of these compounds. An immediate consequence of the increased uptake was a widespread increase in plasma levels of amino acids. On the other hand, the magnitude of non-accounted $\mathrm{N}$ seems not be 
dependent of dietary protein, as previously described [15], remaining to be elucidated the metabolic fate of this $\mathrm{N}$ [24].

The metabolic adjustment of splanchnic organs to a diet of high protein [23] involves an increase in amino acid deamination and an enhanced urea production and excretion. In LHP animal, even so, the increased catabolism of amino acid was accompanied by a normal index of fat deposition. This observation indicates a metabolic pattern relatively normal, in spite of the higher protein in the diet, which was probably no high enough to induce the intense metabolic responses that affect metabolism of amino acid as in the case of the diets that contain $70 \%$ protein [23]. Although LHP energy intake was similar to that of controls, the former increased the efficiency of energy accretion, which resulted in lean and fat bigger. This higher efficiency may be facilitated by the hormonal status derived from the increase of secretagogues [25], but does not appear to be caused by a decrease in thermogenesis [26].

The higher protein intake supports the increased protein catabolism, and the notorious increase in Gly and Taurine levels in urine, coinciding with the standard excretion patterns previously described [27]. Even so, in terms of $\mathrm{N}$ excretion, loss of amino acid accounted for only a scarce $0.1 \%$ of excreted $\mathrm{N}$, the main part excreted like urea (ca $70 \%$ ). Therefore we suppose that the differential excretion has to be in another form, probably so derived of ammonia. The normal amino acid accretion rate in the lean HP group and the maintenance of total amino acid proportion and amount in final homogenates are symptomatic of normal development in relation to control animals. Like this, the moderate level of supplementation of protein in the diet does not induce dramatic changes in metabolism of amino acid neither in deposition of lean mass, just the needed mechanisms to direct the excess of $\mathrm{N}$ ingested.

As expected, the lean rats fed the low protein $\operatorname{diet}$ (LLP), showed the lowest growth rate of the lean groups. Thus, the limitation of protein availability influences the intake, and then the energy available. This stunted growth is the response to limited amino acid availability during juvenile growth period [28] and is not compensated by an increased intake. These animals sacrificed their lean mass accretion, thereby showing a differential substrate partition shifted to lipid accretion, which is in accordance with previous results [17], as a means to save the excess of dietary carbohydrates in a medium deficient in protein. However, this lipid accretion pattern is performed when peripheral lipid utilization is difficult as a consequence of decreased lipoprotein lipase activity [29], and parallel to a decrease in energy accretion and in $\mathrm{N}$ absorption efficiencies. The slower digestion pattern described in these animals [30], seems do not impair amino acid transport [17], although an increased thermogenic response has been described [26], which obviously contributes to lower the energy efficiency. In spite of this reduced amino acid accretion, these animals maintained the same body amino acid composition pattern as the RD group, in a similar way to that described for situations of mild malnutrition that induce "accommodation" [31] and a decrease in both protein synthesis and degradation. Furthermore, the maintenance of the relative proportion of each amino acid in total homogenate, and especially Leu, may be symptomatic of comparative protein synthesis, due to the role of this amino acid in the control of this pathway [32,33]. The relative maintenance of plasma amino acid values, especially essential ones, confirms "accommodation" to a low protein diet, concomitant with a lower, but harmonic, growth rate since the maintenance of body protein mass is critical for survival [34]. The low insulin levels described in animals on LP diets [35], caused by a reduced amount of secretagogues, may contribute to this pattern.

Obese animals present an increased fatty mass [15], as a result of their increased energy efficiency ratio. The characteristic hyperphagia of these animals [36], except for the LP group, implies an increase in $\mathrm{N}$ intake, which is counterbalanced by an augmented $\mathrm{N}$ excretion to maintain the same rate of protein accretion as their lean littermates. This adaptation results in an increase in $\mathrm{N}$ excreted in faeces and especially in urine, where $\mathrm{N}$ from amino acids accounts for only a minor part of total excretion. The increased capacity of obese animals to manage amino acids produces greater metabolic amino acid turnover. As obese animals maintained the same relative percentage of amino acids in total homogenate, and total protein content values, we deduce that the lean mass of these animals is equivalent to their lean littermates [15]. Thus, the genetic background of these animals prevails and limits the lean mass that can be achieved, irrespective of the amount of amino acid availability. The observation that the relative proportion of each amino acid in the total homogenate of obese rats was similar to that of lean animals corroborates the normal growth of the former and does not reflect abnormalities in liver amino acid metabolism [37].

Obese HP animals lost their capacity to increase energy efficiency when compared to control animals, and in spite of keeping the index of accretion of the amino acid, maintaining the amino acid accretion rate, this HP group showed a loss of $\mathrm{N}$ efficiency management, which resulted in increased $\mathrm{N}$ excretion in urine, thereby indicating enhanced amino acid catabolism. The reason why obese rats show an impaired capacity to manage $\mathrm{N}$ remains unclear; there is no evidence that these animals show diminished capacity to manage amino acids, since no changes in amino acid transport systems have been detected in obese rats fed moderate high-protein diets [17]. Consequently, we attributed impaired $\mathrm{N}$ administration to the limited capacity of these animals to accumulate lean mass.

As expected, the growth rate of obese LP group was lower than obese controls in spite of the maintenance of protein and fat content. As in lean animals, there was a noticeable decrease in $\mathrm{N}$ absorption efficiency, which was compensated by lower rates of urine excretion. However, the low intake and excretion of $\mathrm{N}$ resulted in higher accrual efficiency (in relation to absorbed levels). If we consider the maintenance of the relative percentage of each amino acid in the final homogenate (data not shown) we can deduce that the higher efficiency of OLP animals is related to genetic background, where the increase in energy efficiency is paralleled to an increase in metabolic $\mathrm{N}$ efficiency, when compared with LLP group.

\section{CONCLUSIONS}

On the basis of our findings we conclude that Zucker rats accommodate their metabolism to support moderate 
increases in protein intake (doubling the usual intake), with slight changes in nitrogen efficiency management that implies a small increase in lean mass. Instead, these animals do not show adaptive capacity to a decrease of $50 \%$ in protein content. In this case, these animals did not achieve the minimal daily requirements and then, they reduce their growth rate. Finally, the effects caused by protein diets tested here on obese animals were milder than on their lean littermates. These results confirm that changes in protein content in the diet cause in obese animals a different pattern than hypercaloric diets, as previously reported $[15,17]$.

\section{CONFLICT OF INTEREST}

The authors confirm that this article content has no conflicts of interest.

\section{ACKNOWLEDGEMENTS}

This research was supported, in part, by grants SAF200911739 and AGL2011-23635, from the "Plan Nacional" from the Government of Spain. We thank the language advisory service (SAL) of the University of Barcelona for revising of the manuscript.

\section{ABBREVIATIONS}

$\begin{array}{lll}\text { LRD } & = & \text { Lean animals fed reference diet } \\ \text { LHP } & = & \text { Lean animals fed high-protein diet } \\ \text { LLP } & = & \text { Lean animals fed low-protein diet } \\ \text { ORD } & = & \text { Obese animals fed reference diet } \\ \text { OHP } & = & \text { Obese animals fed high-protein diet } \\ \text { OLP } & = & \text { Obese animals fed low-protein diet }\end{array}$

\section{SUPPLEMENTARY MATERIAL}

Supplementary material is available on the publisher's web site along with the published article.

\section{REFERENCES}

[1] Snell K. Protein, amino acid and urea metabolism in the neonate. In: Girard J, Ferré P, Jones CT , Eds. Biochemical development of the fetus and neonate, New York: Elsevier Biomedical Press 2003; pp. 651-91.

[2] Miller SA. Nutrition in the neonatal development of protein metabolism. Fed Proc 1970; 29: 1497-502.

[3] Redman RS, Sweney LR. Changes in diet and patterns of feeding activity of developing rats. J Nutr 1976;106: 615-26.

[4] Pastor-Anglada M, López-Tejero D, Remesar X. Variations in free amino acid in tissues of rats from birth to puberty. Ann Nutr Metab 1987; 31:211-8.

[5] Wapnir RA, Lifshitz F. Absorption of amino acids in malnourished rats. J Nutr 1974; 104:843-9.

[6] Wolfram S, Scharrer E. Effect of feeding a high protein diet on amino acid uptake into rat intestinal brush border membrane vesicles. Pflügers Arch 1984; 400: 34-9.

[7] Masanés RM, Fernández-López JA, Alemany M, Remesar X, Rafecas I. Effect of dietary protein content on tissue protein synthesis rates in Zucker lean rats. Nutr Res 1999; 19: 1017-26.

[8] Millward DJ, Layman DK, Tomé D, Schaafsma G. Protein quality assessment: impact of expanding understanding of protein and amino acid needs for optimal health. Am J Clin Nutr 2008; 87.1576S-81S

[9] Fashakin JB, Fürst P. Effect of dietary protein restriction on urinary nitrogen loss and tissue free amino acid patterns in mature rats. Nutr Res 1987; 7. 285-98.
[10] Stern JS, Johnson PR. Spontaneous activity and adipose cellularity in the genetically obese Zucker rat (fafa). Metabolism 1977; 26: 371-80.

[11] Lanza-Jacoby S, Kaplan ML. Alterations in skeletal muscle proteins in obese and nonobese rats. Int J Obesity 1984; 8: 451-6.

[12] Rafecas I, Esteve M, Fernández-López JA, Remesar X, Alemany M. Whole rat protein content estimation: applicability of the Nx6.25 method. Br J Nutr 1994; 72: 199-209.

[13] Rafecas I, Esteve M, Fernández-López JA, Remesar X, Alemany $M$. Dietary individual amino acid balances in young lean and obese Zucker rats fed a cafeteria diet. Mol Cell Biochem 1993; 121: 4558.

[14] Folch J, Lees M, Sloane-Stanley GH. A simple method for the isolation and purification of total lipids from animal tissues. J Biol Chem 1957; 226: 497-509.

[15] Esteve M, Rafecas I, Remesar X, Alemany M. Nitrogen balances of lean and obese Zucker rats subjected to a cafeteria diet. Int $\mathrm{J}$ Obesity 1992; 16: 237-44.

[16] Ardévol A, Adán A, Remesar X, Fernández-López JA, Alemany M. Hind leg heat balance in obese Zucker rats during exercise. Pflüg Archiv 1998; 435: 495-502.

[17] asanés RM, Rafecas I, Remesar X. The hepatic amino acid system A transport activity is up-regulated in obese Zucker rats. J Nutr Biochem 1999; 10: 716-22.

[18] Pullar JD, Webster AJF. The energy cost of fat and protein deposition in the rat. Br J Nutr 1977; 37: 355-63.

[19] Westerterp-Plantenenga MS. Protein intake and energy balance. Regul Peptides 2008; 149: 67-9.

[20] Diamond JM, Karasov WH. Adaptive regulation of intestinal nutrient transporters. Proc Natl Acad Sci USA 1987; 84: 2242-5.

[21] Stevens BR. Amino acid transport in intestine. In: Kilberg MS, Haussinger D Eds. Amino acid transport: mechanisms and control. New York: Plenum Press 1992. pp. 149-64.

[22] Jean C, Rome S, Mathé V, Huneau J-F, Aattouri N, Fromentin G, Larue C, Tomé D. Metabolic evidence for adaptation to high protein diet in rats. J Nutr 2001; 131: 91-8.

[23] Remesy C, Morand C, Demigné C, Fafornoux P. Control of hepatic utilization of glutamine by transport processes or cellular metabolism in rats fed a high protein diet. J Nutr 1988; 118: 56978 .

[24] Costa G, Ullrich L, Kantor F, Holland JF. Production of elemental nitrogen by certain mammals including man. Nature 1968; 218: 546-51.

[25] Belobrajdic DP, McIntosh GH, Owens JA. A high-whey-protein diet reduces body weight gain and alters insulin sensitivity relative to red meat in Wistar rats. J Nutr 2004; 134:1454-8.

[26] Zhao XQ, Jørgensen H, Gabert VM, Eggum BO. Energy metabolism and protein balance in growing rats housed in 18 degree $\mathrm{C}$ or 28 degree $\mathrm{C}$ environments and fed different levels of dietary protein. J Nutr 1996; 126: 2036-43.

[27] Pastor-Anglada M, Remesar X. Urinary amino acid excretion in pregnant rat. Nutr Res 1986; 6: 709-18.

[28] Dunn MA, Hartsook EW. Comparative amino acid and protein metabolism in obese and non-obese Zucker rats. J Nutr 1980; 110 1865-79.

[29] Boualga A, Bouchenak M, Belleville J. Low-protein diets prevent tissue lipoprotein lipase activity increase in growing rats. Br J Nutr 2000; 84: 663-71.

[30] Masanés RM, Rafecas I, Remesar X. Absorption of a protein gavage in Zucker lean rats. Influence of protein content in the diet. Arch Physiol Biochem 2001; 109: 168-74.

[31] Young VR, Marchini JS. Mechanisms and nutritional significance of metabolic responses to altered intakes of protein and amino acids, with reference to nutritional adaptation in humans. Am J Clin Nutr 1990; 51:270-89.

[32] Garlick PJ. The role of leucine in the regulation of protein metabolism. J Nutr 2005; 135: 1553S-6S.

[33] Zanchi N, Nicastro H, Lancha AH Jr. Potential antiproteolytic effects of L-leucine: observations of in vitro and in vivo studies. Nutr Metab 2008; 5: 20

[34] Timmerman KL, Volpi E. Amino acid metabolism and regulatory effects in aging. Curr Opin Clin Nutr Metab Care 2008; 11: 45-9.

[35] Okitolonda W, Brichard SM, Pottier AM, Henquin JC. Influence of low- and high-protein diets on glucose homeostasis in the rat. $\mathrm{Br} \mathrm{J}$ Nutr 1998; 60: 509-16. 
[36] Morens C, Sirot V, Scheurink AJW, van Dijk G. Low-carbohydrate diets affect energy balance and fuel homeostasis differentially in lean and obese rats. Am J Physiol 2006; 291: R1622-9.
[37] Serkova NJ, Jackman M, Brown JL, Liu T, Hirose R, Roberts JP, Maher JJ, Niemann CU. Metabolic profiling of livers and blood from obese Zucker rats. J Hepatol 2006; 44: 956-62.

Received: Octobere 22, 2012

(C) Rafecas and Remesar; Licensee Bentham Open.

This is an open access article licensed under the terms of the Creative Commons Attribution Non-Commercial License (http://creativecommons.org/licenses/by-nc/3.0/) which permits unrestricted, non-commercial use, distribution and reproduction in any medium, provided the work is properly cited. 